\title{
PENGARUH KEMAMPUAN BERPIKIR KREATIF TERHADAP HASIL BELAJAR SISWA PADA MATA PELAJARAN MATEMATIKA SMP NEGERI 5 PANJI KABUPATEN SITUBONDO
}

\author{
Sahwari ${ }^{1}$, Dassucik ${ }^{2}$ \\ ${ }^{1,2}$ STKIP PGRI SITUBONDO \\ Correspondence email: sahwari52@gmail.com
}

\begin{abstract}
ABSTRAK
Berpikir kreatif adalah dimana seseorang bisa menciptakan pemikiran atau ide baru tentang sesuatu, dalam hal ini pemikiran atau ide baru dalam menyelesaikan persoalan dalam matematika dengan cara yang lebih sederhana, cepat, dan mudah dimengerti. Penelitian ini bertujuan untuk mengetahui adanya pengaruh berpikir kreatif terhadap hasil belajar mata pelajaran matematika. Penelitian ini merupakan penelitian kuantitatif dengan subjek penelitian siswa kelas VII, VIII dan IX SMP Negeri 5 Panji dengan Jumlah keseluruhan siswa 89 diambil keseluruhan. Proses penelitian dilakukan dalam dua tahap. Tahap pertama pengumpulan data dengan menggunakan metode angket untuk mengetahui kemampuan berpikir kreatif. Hal ini dibuktikan dari hasil analisis data menunjukkan bahwa kemampuan berpikir kreatif terhadap hasil belajar siswa ada pengaruh yang positif, ditunjukkan dengan harga $r$ hitung $(0,296)$ yang lebih besar dari pada $r$ tabel $(0,206)$ dan dengan harga $t$ hitung $(2,887)$ yang lebih besar dari pada $t$ tabel $(1,662)$. Persamaan garis regresi pengaruh kemampuan berpikir kreatif terhadap hasil belajar mata pelajaran matematika dapat dinyatakan dengan $\mathrm{Y}=73,082 \mathrm{a}+0,240 \mathrm{~b}$. Persamaan tersebut menunjukan bahwa nilai koefisien X sebesar 0,240. Dari hasil uji hipotesis ini menunjukan bahwa Ha diterima dan Ho ditolak, dapat di katakan ada pengaruh antara kemampuan berpikir kreatif terhadap hasil belajar mata pelajaran matematika. Besarnya sumbangan kemampuan berpikir kreatif terhadap hasil belajar ditunjukkan dengan analisis regresi sederhana yang ditemukan sumbangan efektif sebesar $14,49 \%$ sedang variabel lainnya yang tidak diteliti adalah sebesar $85,51 \%(100 \%-14,49 \%)$.
\end{abstract}

Kata kunci: berpikir kreatif, hasil belajar mata pelajaran matematika

\section{PENDAHULUAN}

Pada dasarnya pendidikan merupakan hal yang sangat penting dalam kehidupan kita yang tidak pernah selesai sampai kapan pun, sepanjang ada kehidupan manusia di dunia ini. Dikatakan demikian, karena pendidikan merupakan bagian dari kebudayaan dan peradaban manusia yang terus berkembang. Hal ini sejalan dengan pembawaan manusia yang memiliki potensi kreatif dan inovatif dalam segala bidang kehidupannya.

Menurut Trianto (2007: 1) dalam situasi masyarakat yang selalu berubah, idealnya pendidikan tidak hanya berorientasi pada masa lalu dan masa kini, tetapi sudah seharusnya merupakan proses yang mengantisipasi dan membicarakan masa depan. Pendidikan 
hendaknya melihat jauh ke depan dan memikirkan apa yang akan dihadapi peserta didik di masa yang akan datang.

Pendidikan merupakan wahana yang penting dalam upaya meningkatkan kualitas sumber daya manusia. Upaya peningkatan sistem pendidikan untuk mampu menciptakan sumber daya manusia yang andal, pemerintah berupaya melakukan peningkatan kualitas proses dan hasil belajar pada setiap jenjang tingkatan pendidikan, agar memperoleh sumber daya manusia yang dapat menunjang pembangunan pendidikan nasional. Selaras dengan perkembangan ilmu sains, teknologi dan keanekaragaman suku bangsa, karena suatu bangsa memerlukan sumber daya manusia yang kreatif dan unggul untuk dapat digunakan. Dimana pada tingkatan tingkat perguruan tinggi menuntut mahasiswa untuk memiliki kemampuan kreatif dalam berpikir dan perilaku yang dimiliki

Kemampuan berpikir kreatif erat kaitannya dengan proses berpikir kreatif, dan proses berpikir kreatif berkaitan dengan proses mencipta (Abidin, Rohaeti, \& Afrilianto, 2018). Mencipta artinya meletakkan elemen-elemen secara bersama-sama untuk membentuk suatu keseluruhan yang berkaitan dan fungsional atau mengatur kembali elemen-elemen ke dalam suatu struktur atau pola-pola baru (Siswono, 2008). Berpikir kreatif (creative thingking) merupakan keterampilan yang penting untuk dikembangkan oleh setiap mahasiswa dalam mempersiapkan diri dalam bersaing sebagai sumber daya manusia yang unggul (Abidin et al., 2018). Berpikir kreatif merupakan bagian dari keterampilan berpikir tingkat tinggi (higherorder thingking skills). Pentingnya berpikir kreatif yaitu sebagai cara menghasilkan ide-ide yang dapat diterapkan kepada masalah dunia (Anwar, Aness, Khizar, Naseer, \& Muhammad, 2012).

Kreativitas sangat penting dikarenakan, ketika seseorang menemukan kreativitasnya, mereka cenderung menjadi mandiri, percaya diri, berani mengambil resiko, berenergi tinggi, antusias, spontan, suka berpetualang, cermat, selalu ingin tahu, humoris, dan polos seperti anak-anak. Walaupun mengenali sifat-sifat yang mendorong kreativitas merupakan hal yang penting, lebih penting lagi mengingatbahwa kita semua terlahir dengan kemampuan mencipta. Sementara itu, untuk memahami proses kreativitas dapat meningkatkan kemampuan berpikir kreatif kita, karena kreativitas merupakan syarat dari berpikir kreatif.

Seseorang tidak akan pernah berpikir dan bertindak kreatif selama pola pikirnya terikat atau bahkan oleh berbagai peraturan maupun berbagai perilaku yang dibentuk oleh kebiasaan-kebiasaan. Masyarakat yang tertutup apalagi peranan kekuasaan terlalu besar pengaruhnya terhadap kehidupan akan sulit diharapkan memperoleh semangat kreativitas. bahwa persyaratan utama dari kreativitas adalah adanya kelapangan dan suasana yang 
memungkinkan seseorang dapat melakukan improvisasi atau bahkan melawan arus dari kebiasaan-kebiasaan. Salah satu cara menjadi manusia kreatif kita harus mampu mendobrak kebiasaan.

Pembelajaran merupakan kegiatan utama dalam lingkungan sekolah yang menjadi penentu kualitas Output sumber daya manusia. Oleh sebab itu upaya peningkatan kualitas pembelajaran menjadi kebutuhan yang signifikan. Dalam kegiatan belajar mengajar di sekolah sering dijumpai beberapa masalah. Banyak dijumpai siswa yang mempunyai nilai rendah dalam sejumlah mata pelajaran, khususnya pelajaran matematika. Prestasi belajar yang dicapai belum memuaskan mengingat masih banyak siswa yang memperoleh nilai di bawah standar yang ditetapkan.keberhasilan pembelajaran tidak hanya dipengaruhi oleh metode pembelajaran tetapi juga dipengaruhi oleh kemampuan berpikir kreatif siswa. Siswa yang kreatif dalam proses belajar mengajar dimungkinkan memiliki hasil belajar yang tinggi.

\section{METODE PENELITIAN}

Untuk membantu dan menunjang penelitian ini, metode yang digunakan yaitu metode angket. angket yang digunakan oleh peneliti berbentuk pertanyaan tertutup, dimana responden hanya memberi jawaban yang tersedia dalam angket. Sampel dalam penelitian ini siswa kelas VII, VIII dan IX di SMP Negeri 5 Panji yang berjumlah 89 siswa. Setelah data diperoleh selanjutnya yaitu analisa data. Analisa data yang digunakan dalam penelitian ini yaitu dengan Uji prasyarat dan Uji hipotesis dengan bantuan aplikasi SPSS. SPSS for Windows release 20.0

Adapun tahapan yang dilakukan sebagai berikut :

a. Uji Prasyarat

1. Uji validitas, tahapan awal untuk menguji valid tidaknya suatu instrumen yang digunakan. Dengan bantuan SPSS menggunakan rumus korelasi Product Moment Pearson.

2. Uji reliabilitas, mengetahui akurasi pertanyaan dalam menghasilkan data yang reliabel. Uji reliabilitas angket menggunakan reliabilitas Cronbach's Alpha.

3. Uji linearitas, mengetahui apakah dua variabel mempunyai hubungan yang linear secara signifikan atau tidak.

b. Uji Hipotesis

Tahapan awal menggunakan analisis korelasi sederhana dan dilanjutkan dengan analisis korelasi berganda. Uji hipotesis digunakan untuk mengetahui korelasi antar variabel. 
Data tentang kemampuan berpikir kreatif siswa ini didapat dari hasil penyebaran angket tentang kemampuan berpikir kreatif siswa yang dilakukan pada saat penelitian. Dari hasil penyebaran angket tersebut kemudian data diolah sehingga diporeh data yang berupa nilai. Setelah diadakan penskoran atau penilaian hasil angket, maka dapat dilakukan analisis dengan menggunakan rumus Struges.

Dengan demikian dapat diperoleh kualifikasi dan interval nilai seperti pada tabel dibawah ini:

\section{Tabel 1}

Daftar Distribusi Frekuensi Tingkat Kemampuan Berpikir Kreatif

\begin{tabular}{|c|c|c|c|}
\hline No & Interval & Frekuensi & Presentase $\%$ \\
\hline 1 & $32-35$ & 4 & $4,5 \%$ \\
\hline 2 & $36-39$ & 17 & $19,1 \%$ \\
\hline 3 & $40-43$ & 36 & $40,4 \%$ \\
\hline 4 & $44-47$ & 18 & $20,3 \%$ \\
\hline 5 & $48-51$ & 11 & $12,4 \%$ \\
\hline 6 & $52-55$ & 0 & $0 \%$ \\
\hline 7 & $56-59$ & 1 & $1 \%$ \\
\hline 8 & $60-63$ & 2 & $2,3 \%$ \\
\hline \multicolumn{2}{|c|}{ Jumlah } & 89 & $100 \%$ \\
\hline
\end{tabular}

Berdasarlan tabel 1 distribusi frekuensi variabel kemampuan berpikir kreatif dengan kelas interval sebesar 8 dan panjang kelas sebasar 4, maka dapat diketahui sebanyak 4,5\% dengan frekuensi sebesar 4 terletak pada interval 32-35, 19,1\% dengan frekuensi sebesar 17 terletak pada interval 36-39, 40,4\% dengan frekuensi sebesar 36 terletak pada interval 4043,20,3\% dengan frekuensi sebesar 18 terletak pada interval 44-47,12,4\% dengan frekuensi sebesar 11 terletak pada interval 48-51,0\% dengan frekuensi sebesar 0 terletak pada interval $52-55,1 \%$ dengan frekuensi sebesar 1 terletak pada interval 56-59, 2,3\% dengan frekuensi sebesar 2 terletak pada interval 60-63.Sehingga dapat dilihat dalam histogram sebagai berikut: 


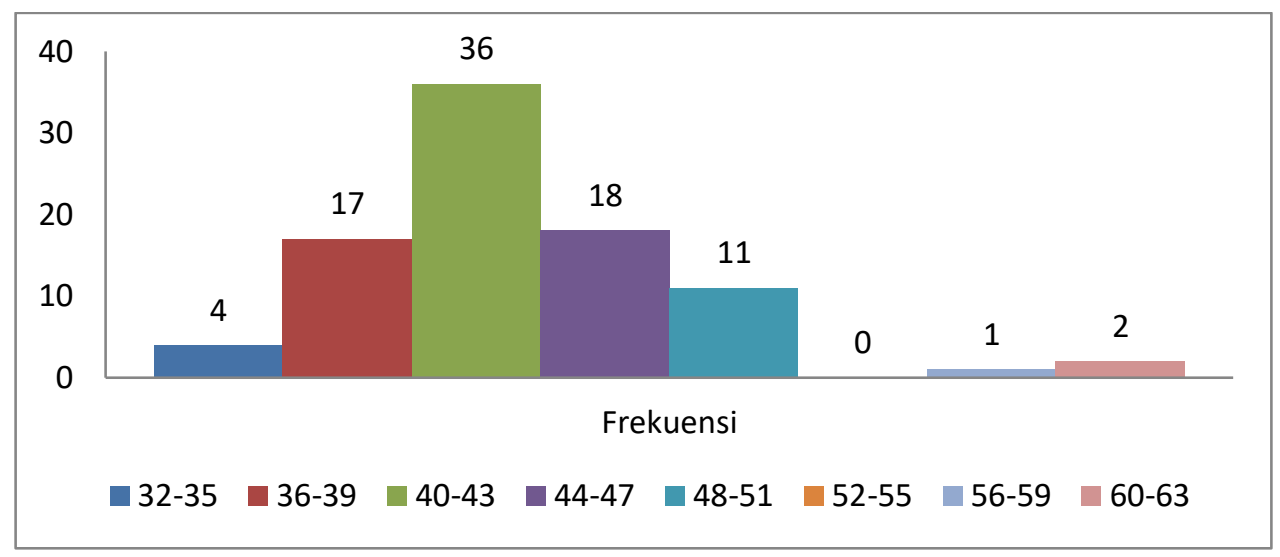

Gambar 1 Histogram kemampuan berpikir kreatif

Berdasarkan gambar 1 histogram distribusi frekuensi variabel kondisi kemampuan berpikir kreatif siswa dapat diketahui bahwa frekuensi terbesar berada pada interval 40-43 dengan sebesar 36, sedangkan frekuensi terkecil terletak pada interval 52-55 dengan frekuensi sebesar 0.

Data tentang hasil belajar siswa ini didapat dari hasil ulangan harian. Setelah diadakan penskoran atau penilaian hasil ulangan harian dengan rumus Struges. Dengan demikian dapat diperoleh kualifikasi dan interval nilai seperti pada tabel dibawah ini:

Tabel 2

Daftar Distribusi Frekuensi Tingkat hasil belajar

\begin{tabular}{|c|c|c|c|}
\hline No & Interval & Frekuensi & Presentase $\%$ \\
\hline 1 & $80-82$ & 47 & $53 \%$ \\
\hline 2 & $83-85$ & 20 & $23 \%$ \\
\hline 3 & $86-88$ & 11 & $12 \%$ \\
\hline 4 & $89-91$ & 8 & $9 \%$ \\
\hline 5 & $92-94$ & 1 & $1 \%$ \\
\hline 6 & $95-97$ & 1 & $1 \%$ \\
\hline 7 & $98-100$ & 1 & $1 \%$ \\
\hline \multicolumn{2}{|c|}{ Jumlah } & 89 & $100 \%$ \\
\hline
\end{tabular}

Berdasarlan tabel 2 distribusi frekuensi variabel hasil belajar siswa dengan kelas interval sebesar 8 dan panjang kelas sebasar 3, maka dapat diketahui sebanyak 53\% dengan frekuensi sebesar 47 terletak pada interval 80-82, 23\% dengan frekuensi sebesar 20 terletak pada interval 83-85, $12 \%$ dengan frekuensi sebesar 11 terletak pada interval 86-88,9\% dengan frekuensi sebesar 8 terletak pada interval 89-91,1\% dengan frekuensi sebesar 1 terletak pada interval 92-94, 1\% dengan frekuensi sebesar 1 terletak pada interval 95-97, $1 \%$ dengan frekuensi sebesar 1 terletak pada interval 98-100.Sehingga dapat dilihat dalam histogram dibawah ini: 


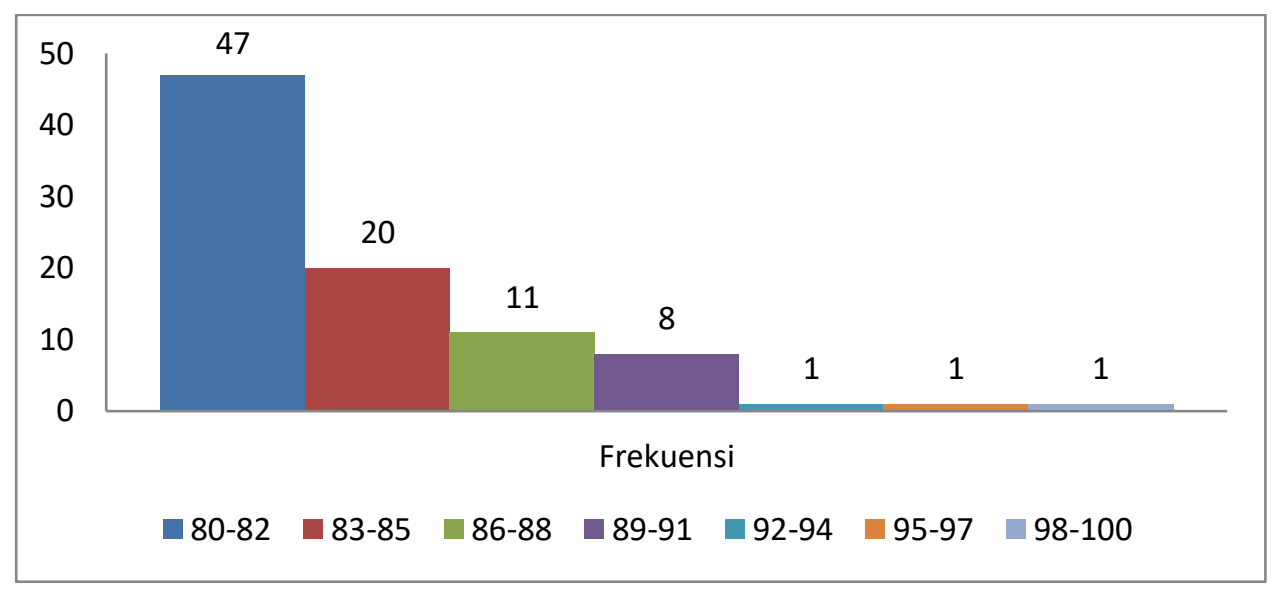

Gambar 2 Data variabel $Y$ hasil belajar siswa

Berdasarkan gambar 2 histogram distribusi frekuensi variabel hasil belajar siswa dapat diketahui bahwa frekuensi terbesar berada pada interval 80-82 dengan sebesar 47, sedangkan frekuensi terkecil terletak pada interval 92-94, 95-97, 98-100 dengan frekuensi sebesar 1.

\section{ANALISIS DATA}

Mengukur tingkat kevalidan atau kesahihan sesuatu instrumen. Suatu instrumen yang valid atau sahih mempunyai validitas tinggi. Penghitungannya menggunakan rumus Korelasi Product-Moment Person dan di hitung dengan bantuan SPSS for Windows release 20.0 dapat dilihat dalam tabel berikut ini:

Tabel 3

Hasil Uji Validitas

\begin{tabular}{|c|c|c|c|c|}
\hline No Soal & Asymp sig & Taraf Signifikansi & $r_{\text {tabel }}$ & Kesimpulan \\
\hline 1 & 0,256 & $5 \%$ & 0,206 & Valid \\
\hline 2 & 0,452 & $5 \%$ & 0,206 & Valid \\
\hline 3 & 0,257 & $5 \%$ & 0,206 & Valid \\
\hline 4 & 0,219 & $5 \%$ & 0,206 & Valid \\
\hline 5 & 0,363 & $5 \%$ & 0,206 & Valid \\
\hline 6 & 0,396 & $5 \%$ & 0,206 & Valid \\
\hline 7 & 0,341 & $5 \%$ & 0,206 & Valid \\
\hline 8 & 0,391 & $5 \%$ & 0,206 & Valid \\
\hline 9 & 0,375 & $5 \%$ & 0,206 & Valid \\
\hline 10 & 0,313 & $5 \%$ & 0,206 & Valid \\
\hline 11 & 0,479 & $5 \%$ & 0,206 & Valid \\
\hline 12 & 0,390 & $5 \%$ & 0,206 & Valid \\
\hline 13 & 0,485 & $5 \%$ & 0,206 & Valid \\
\hline 14 & 0,382 & $5 \%$ & 0,206 & Valid \\
\hline 15 & 0,412 & $5 \%$ & 0,206 & Valid \\
\hline 16 & 0,242 & $5 \%$ & 0,206 & Valid \\
\hline 17 & 0,275 & $5 \%$ & 0,206 & Valid \\
\hline 18 & 0,476 & $5 \%$ & 0,206 & Valid \\
\hline 19 & 0,352 & $5 \%$ & 0,206 & Valid \\
\hline
\end{tabular}




\begin{tabular}{|l|l|l|l|l|}
\hline 20 & 0,430 & $5 \%$ & 0,206 & Valid \\
\hline
\end{tabular}

Berdasarkan tabel di atas menunjukkan bahwa data tersebut memiliki distribusi data normal karena mempunyai nilai yang lebih besar dai taraf signifikansi 5\% dengan $r_{\text {tabel }}$ $(0,206)$. Variabel kemampuan berpikir kreatif siswa menunjukkan nilai $r_{\text {hitung }}>r_{\text {tabel }}$. Maka dapat disimpulkan data penelitian ini layak dilanjutkan untuk menguji hipotesis.

Selain harus valid, instrumen juga harus memenuhi standar reliabilitas. Suatu instrumen dikatakan reliabel jika dapat dipercaya untuk mengumpulkan data penelitian. Dalam menghitung reliabilitas instrumen, peneliti menggunkan rumus Cronbach's Alpha dan dihitung dengan bantuan SPSS for Windows release 20.0 Instrumen dikatakan reliabel jika rhitung $\geq \mathrm{r}$ tabel dan sebaliknya jika $\mathrm{r}$ hitung $<\mathrm{r}$ tabel maka instrument dikatakan tidak reliable. Berikut hasil uji reliabilitas:

Tabel 4 : Hasil Uji Reliability

Case Processing Summary

\begin{tabular}{|rl|r|r|}
\hline & & \multicolumn{1}{|c|}{$\mathrm{N}$} & \multicolumn{2}{|c|}{$\%$} \\
\hline \multirow{3}{*}{ Cases } & Valid $^{2}$ & 89 & 100,0 \\
& Excluded $^{\mathrm{a}}$ & 0 &, 0 \\
& Total $^{2}$ & 89 & 100,0 \\
\hline
\end{tabular}

a. Listwise deletion based on all variables in the procedure.

Reliability Statistics

\begin{tabular}{|r|r|}
\hline $\begin{array}{c}\text { Cronbach's } \\
\text { Alpha }\end{array}$ & $\begin{array}{c}\text { N of } \\
\text { Items }\end{array}$ \\
\hline, 657 & 20 \\
\hline
\end{tabular}

Tabel 5 : Interpretasi Reliabilitas

\begin{tabular}{|c|c|}
\hline Interval Korelasi & Tingkat Korelasi \\
\hline $0,00-0,19$ & Sangat Rendah \\
$0,20-0,39$ & Rendah \\
$0,40-0,59$ & Sedang \\
$\mathbf{0 , 6 0}-\mathbf{0 , 7 9}$ & Kuat \\
$0,80-1,00$ & Sangat Kuat \\
\hline
\end{tabular}

Hasil uji reliabilitas instrumen penelitian menunjukkan variabel kemampuan berpikir kreatif memiliki reabilitas kuat sebesar 0,657 dan $r$ hitung $\geq r$ tabel $(0,657 \geq 0,206)$. 
Untuk Mencari keofisien korelasi ini ingin mengetahui hubungan anatara variabel X dengan Y, adapun rumus yang di gunakan yaitu menggunakan rumus Korelasi ProductMoment Person dan dihitung dengan bantuan SPSS for Windows release 20.0 hasilnya dapat dilihat dalam tabel berikut

Tabel 6: Correlations

\begin{tabular}{|rl|r|r|}
\hline & & X & \multicolumn{1}{|c|}{ Y } \\
\hline \multirow{3}{*}{ X } & Pearson Correlation & 1 &, $296^{* *}$ \\
& Sig. (2-tailed) & &, 005 \\
& N & 89 & 89 \\
Y & Pearson Correlation &, $296^{* *}$ & 1 \\
& Sig. (2-tailed) &, 005 & \\
& N & 89 & 89 \\
\hline
\end{tabular}

**. Correlation is significant at the 0.01 level (2-tailed).

Tabel 7. Interpretasi korelasi

\begin{tabular}{|c|c|}
\hline Interval Korelasi & Tingkat Korelasi \\
\hline $0,00-0,19$ & Sangat Rendah \\
$\mathbf{0 , 2 0}-\mathbf{0 , 3 9}$ & Rendah \\
$0,40-0,59$ & Sedang \\
$0,60-0,79$ & Kuat \\
$0,80-1,00$ & Sangat Kuat \\
\hline
\end{tabular}

Dari Hasil SPSS for Windows release 20.0 menunjukkan $\mathrm{t}$ hitung $=0,296$ melainkan dengan sig $=0,005$, Dan dari hasil uji sinifikansi korelasi menunjukkan $\mathrm{t}$ hitung $=2,89088$ sedangkan $\mathrm{t}$ tabelnya $=1.66216$, maka $(\mathrm{t}$ hitung $>\mathrm{t}$ tabel $)$. Jadi $\mathrm{Ha}=$ diterima dan $\mathrm{Ho}=$ ditolak. Dengan kata lain bahwa tingkat hubungan antara variabel $X$ terhadap variabel $Y$ bersifat rendah.

Persamaan regresi linier sederhana (dengan satu prediktor) dapat dirumuskan sebagai berikut referensinya: $\mathrm{Y}=\mathrm{a}+\mathrm{bx}$. Kemudian untuk Koefisien regresi linearnya a dan $\mathrm{b}$, dihitung dengan rumus sebangai berikut:

$$
\begin{aligned}
& \mathrm{a}=\frac{\left(\sum \mathrm{Y}\right)\left(\sum \mathrm{X}^{2}\right)-\left(\sum \mathrm{X}\right)\left(\sum \mathrm{XY}\right)}{\mathrm{n} \sum \mathrm{X}^{2}-\left(\sum \mathrm{x}\right)^{2}} \\
& \mathrm{~b}=\frac{\mathrm{N} \sum \mathrm{XY}-\left(\sum \mathrm{X}\right)\left(\sum \mathrm{Y}\right)}{\mathrm{n} \sum \mathrm{X}^{2}-\left(\sum \mathrm{x}\right)^{2}}
\end{aligned}
$$

Dimana: 
$Y=$ Nilai yang diprediksikan/Nilai Variabel dependent

$a=$ Konstanta atau bila harga $X=0$

$b=$ Koefisien regresi.

Uji hipotesis dilakukan dengan menggunakan analisis regresi sederhana menggunakan bantuan program komputer SPSS for Windows release 20.0 yang hasilnya dapat dilihat pada tabel berikut:

Tabel 8: Ringkasan Hasil Analisis Regresi Sederhana

\begin{tabular}{|c|c|c|c|c|c|c|c|c|}
\hline \multirow[t]{2}{*}{ Variabel } & \multicolumn{3}{|c|}{$\begin{array}{c}\text { Harga } r \text { dan } \\
r^{2}\end{array}$} & \multicolumn{2}{|c|}{ Harga $t$} & \multirow[t]{2}{*}{ Koef } & \multirow[t]{2}{*}{ Konst } & \multirow[t]{2}{*}{ Ket } \\
\hline & $\mathrm{R}$ & $r^{2}$ & $r_{\text {tabel }}$ & $t_{\text {hitung }}$ & $t_{\text {tabel }}$ & & & \\
\hline $\mathrm{XY}$ & 0,296 & 0,087 & 0,206 & 2,887 & 1,662 & 0,240 & 73,082 & ada pengaruh \\
\hline
\end{tabular}

Dari data di atas menunjukkan bahwa kemampuan berpikir kreatif terhadapat hasil belajar siswa ada pengaruh yang positif, ditunjukan dengan harga $r$ hitung $(0,296)$ yang lebih besar dari pada $\mathrm{r}$ tabel $(0,206)$ dan dengan harga $t$ hitung $(2,887)$ yang lebih besar dari pada $t$ tabel $(1,662)$. Persamaan garis regresi pengaruh kemampuan berpikir kreatif terhadap hasil belajar siswa dapat dinyatakan dengan $\mathrm{Y}=73,082 \mathrm{a}+0,240 \mathrm{~b}$. Persamaan tersebut menunjukan bahwa nilai koefisien X sebesar 0,240. Dari hasil uji hipotesis ini menunjukan bahwa Ha diterima dan Ho ditolak, dapat di katakan ada pengaruh antara kemampuan berpikir kreatif terhadap hasil belajar siswa mata pelajaran matematika SMP Negeri 5 Panji.

Untuk pengujian hipotesis, yaitu untuk mengetahui apakah satu variabel perdiktor yang diteliti merupakan suatu variabel yang signifikan terhadap kriteriumnya, digunakan analisa Freg. Analisa tersebut adalah:

$$
F_{\text {reg }}=\frac{R^{2}(N-m-1)}{m\left(1-R^{2}\right)}
$$

\section{Keterangan:}

$N=$ banyaknya anggota responden

$m=$ banyaknya variabel bebas yang diteliti

$R=$ koefisien korelasinya

Dimana nilai $\mathrm{R}^{2}$ merupakan nilai pangkat dua dari koeffisien korelasi (rxy) atau koefisien determinasi yang besarnya sama dengan $\left(r_{x y}^{2}\right)$ atau $(0,296)^{2}=0,087$, sehingga nilai $\mathrm{F}_{\text {reg }}=8,29025191$.

Nilai $F_{\text {reg }}$ ini dikonsultasikan dengan nilai $\mathrm{F}$ tabel, dimana dalam $\mathrm{F}$ tabel dengan taraf signifikansi adalah $d b_{(\mathrm{N}-\mathrm{m}-1)}$, maka $\mathrm{db}=1 / 87$, maka $\mathrm{db}=87$ diketemukan sebesar 3,950 
yang berarti bahwa nilai $F$ hitung lebih besar dari nilai $F$ tabel $(8,290>3,950)$ sehingga terdapat signifikansi antara variabel bebas dengan variabel terikat atau dengan kata lain bahwa hipotesis kerja yang diajukan diterima dan hipotesis nihil ditolak. Atau hipotesis (Ho) ditolak dan (Ha) diterima.

Tabel 9 : Hasil Analisis Varians

\begin{tabular}{|c|c|c|c|c|}
\hline Variabel & F hitung & F tabel & Sig & Keterangan \\
\hline Kemampuan berpikir kreatif & 8,290 & 3,950 & 0,005 & Linier \\
\hline
\end{tabular}

Perhitungan analisa efektifitas garis regresi merupakan suatu penilaian untuk mengetahui tentang penyebaran/nilai sebar dari variabel bebas terhadap variabel terikat, atau merupakan jumlah sumbangan keseluruhan variabel prediktor yang diteliti terhadap kriterium. Dengan demikian berarti bahwa jumlah sumbangan keseluruhan prediktor yang diteliti terhadap kriteriumnya adalah sebesar $8,74 \%$, sedang variabel lainnya yang tidak diteliti adalah sebesar 91,26\%(100\%-8,74\%).

Hasil dari perhitungan besarnya sumbangan efektif kemampuann berpikir kratif terhadap hasil belajar siswa ditunjukkan dengan analisis regresi sederhana yang ditemukan sumbangan efektif sebesar 14,49\% sedang variabel lainnya yang tidak diteliti adalah sebesar $85,51 \%(100 \%-14,49 \%)$.

Siswono (2010) mengatakan berpikir kreatif matematik sebagai kombinasi dari berpikir logis dan divergen yang didasarkan pada intuisi namun masih dalam kesadaran. Ketika seseorang menerapkan berpikir kreatif untuk memecahkan masalah, maka pemikiran divergen akan menghasilkan ide atau gagasan baru. Berpikir logis melibatkan proses rasional dan sistematis untuk memeriksa dan membuat simpulan. Sedangkan berpikir divergen dianggap sebagai kemampuan berpikir untuk mencari ide-ide untuk menyelesaikan masalah.

Besarnya sumbangan kemampuan berpikir kreatif terhadap hasil belajar ditunjukkan dengan analisis regresi sederhana yang ditemukan sumbangan efektif sebesar 14,49\%. sedang variabel lainnya yang tidak diteliti adalah sebesar 85,51\% (100\% - 14,49\%). Dengan demikian dapat disimpulkan bahwa semakin tinggi kemampuan berpikir kreatif, maka semakin tinggi pula hasil belajar siswa. Sebaliknya, semakin rendah kemampuan berpikir kreatif, maka semakin rendah juga hasil belajar siswa. Hal ini sesuai dengan kerangka pikir, yaitu semakin tinggi kemampuan berpikir kreatifnya, maka semakin tinggi hasil belajar. 


\section{DAFTAR PUSTAKA}

Abdusysyakir. 2007. Sejarah Matematika dan Perkembangannya.Yogyakarta: Tiara Wacana Yogya.

Abidin, J., Rohaeti, E. E., \& Afrilianto, M. (2018). Analisis Kemampuan Berfikir Kreatif Matematis Siswa SMP Kelas VIII Pada Materi Bangun Ruang. JPMI (Jurnal Pembelajaran Matematika Inovatif), 1(4), 779. https://doi.org/10.22460/jpmi.v1i4.p779$\underline{784}$

Adijaya, N., \& Santosa, L. P. (2018). Persepsi Mahasiswa dalam Pembelajaran Online. Wanastra, 10(2), 105-110.

Ahmadin, H. A. (2005). Psikologi Perkembangan. Jakarta: Renika Cipta.

Anwar, M. N., Aness, M., Khizar, A., Naseer, M., \& Muhammad, G. (2012). Relationship of creative thinking with the academic achievements of secondary school students. International Interdisciplinary Journal of Education, 1(3), 1-4. Retrieved from https://www.researchgate.net/publication/338549060_Relationship_of_Creative_Thinki ng_with_the_Academic_Achievements_of_Secondary_School_Students

Amirin,Tatang M. 2011. Populasi dan Sampel Penelitian. Tatangmanguny. Wordpress. Com

Armandita, P., Wijayanto, E., Rofiatus, L., \& Susanti, A. (2017). Analisis Kemampuan Berpikir Kreatif Pembelajaran Fisika Di Kelas XJ Mia 3 Sma Negeri 11 Kota Jambi. Penelitian Ilmu Pendidikan, 10(2).

Arikunto,Suharsimi. 2010. Prosedur Penelitian Suatu Pendekatan Praktik, Jakarta:PT Rineka Cipta,

Ayu, P., \& Qohar, A. (2019). Pengembangan Media Pembelajaran Matematika Interaktif Berbasis Powerpoint pada Materi Kerucut, 10(2), 119-124.

Hamalik Oemar. (1992). Psikoligi Belajar Mengajar. Bandung: Sinar Baru.

Hamalik, Oemar. 2003. Proses Belajar Mengajar. Jakarta: Bumi Asara

Hasbullah. 2005. Metodologi Penelitian, Yogyakarta: UPP AMP YKPN

Purwanto. 2011. Evaluasi Hasil Belajar. Penerbit Pustaka Belajar,Yogyakarta.

Potur, A. A., \& Barkul, mr. (2009). Gender and creative thinking in education: A theoretical and experimental overview. A|Z ITU Journal of Faculty of Architecture, 6(2), 44-57.

Shanti, W. N., Sholihah, D. A., \& Abdullah, A. A. (2018). Meningkatkan kemampuan berpikir kritis melalui ctl. Jurnal Pembelajaran Matematika, 5(1), 98-110.

Slameto. 2010. Belajar Dan Faktor-Faktor Yang Mempengaruhi. Jakarta: Rineka Cipta.

Slameto. 2001. Evaluasi Pendidikan. Jakarta. PT. Bumi Aksara 
Sudjana, Nana. 2003. Penilaian Hasil Proses Belajar Mengajar. Bandung: Remaja Rosdakarya.

Sudjana. 2001. Teknik Analisis Regresi dan Korelasi. Bandung:Tarsito

Sukardi. 2003. Metodologi Penelitian Pendidikan (Kompetensi dan Praktiknya). Jakarta: Bumi Aksara.

Sugiyono. 2009. Metode Penelitian Bisnis (Pendekatan Kuantitatif, Kualitatif, dan R\&D). Bandung: Alfabeta.

Sugiyono. (2014). Metode Penelitian Kuantitatif, Kualitatif dan R\&D. Bandung: Alfabeta.

Wicaksono, S. (2016). the Development of Interactive Multimedia Based Learning Using Macromedia Flash 8 in Accounting Course. Journal of Accounting and Business Education, 1(1), 122. https://doi.org/10.26675/jabe.v1i1.6734

Zahara, H. M., \& Budiyono. (2019). Pengaruh Media Papan Penjumlahan Terhadap Hasil Belajar Matematika Materi Penjumlahan Siswa Kelas I Sekolah dasar. Jurnal Penelitian Pendidikan Guru Sekolah Dasar, 